\title{
Penerjemahan Bahasa Indonesia ke Bahasa Minang dari Optical Character Recognition dengan Menggunakan Algoritme Edit Distance
}

\author{
Translating Indonesian into Minang Languages from Optical \\ Character Recognition Using the Edit Distance Algorithm
}

\author{
MAYANDA MEGA SANTONI ${ }^{1 *}$, NURUL CHAMIDAH ${ }^{1}$, DESTA SANDYA PRASVITA $^{1}$, \\ REZA AMARTA PRAYOGA ${ }^{2}$, BAYU PERMANA SUKMA ${ }^{2}$
}

\begin{abstract}
Abstrak
Tri Gatra Bangun Bahasa yaitu utamakan bahasa Indonesia, lestarikan bahasa daerah dan kuasai bahasa asing. Melalui ini, maka bahasa daerah sebagai salah satu kekayaan bangsa Indonesia perlu dilestarikan. Selain itu, bahasa daerah juga berfungsi sebagai pendukung bahasa nasional yakni bahasa Indonesia. Pemanfaatan teknologi dapat digunakan sebagai upaya dalam pelestarian bahasa daerah. Penelitian ini memanfaatkan teknologi kecerdasan buatan yakni mesin penerjemah yang menerjemahkan bahasa Indonesia ke bahasa daerah berbasiskan citra teks. Bahasa daerah yang digunakan yakni bahasa daerah Minang. Fokus penelitian ini pada proses penerjemahan hasil Optical Character Recognition (OCR) dari citra teks bahasa Indonesia menggunakan algoritme Edit Distance, yakni Hamming Distance, Leveinshtein Distance dan Jaro-Winkler. Hasil penelitian ini menunjukkan bahwa algoritme Edit Distance dapat memperbaiki hasil OCR dalam melakukan penerjemahan ke bahasa daerah. Hasil OCR pada citra teks memiliki akurasi awal yakni 50.72\%. Setelah diterapkan algoritme Edit Distance, akurasi penerjemahan meningkat menjadi 68.34\% untuk algoritme Hamming Distance, $70.5 \%$ untuk algoritme Leveinshtein Distance dan 70.2\% untuk algoritme Jaro-Winkler. Dari ketiga algoritme ini, Leveinshtein Distance memiliki performasi akurasi penerjemahan paling tinggi.
\end{abstract}

Kata Kunci: penerjemahan, bahasa indonesia, bahasa minang, hamming distance, leveinshtein distance, jarowinkler, optical character recognition

\begin{abstract}
Tri Gatra Bangun Bahasa, namely prioritizing Indonesian, preserving local languages and mastering foreign languages. Through this, the local language as one of the wealth of the Indonesian nation needs to be preserved. In addition, local languages also function as a supporter of the national language, namely Indonesian. The use of technology can be used as an effort to preserve local languages. This study utilizes artificial intelligence technology, namely machine translation that translates Indonesian into local languages based on text images. The local language used is the Minang language. The focus of this research is the process of translating the results of Optical Character Recognition from Indonesian text images using the edit distance algorithm, namely Hamming distance, Leveinshtein distance and Jaro-Winkler. The results of this study indicate that the edit distance algorithm can improve the OCR results in translating into local languages. OCR results on text images have an initial accuracy of 50.72\%. After applying the edit distance algorithm, the translation accuracy increases to $68.34 \%$ for the Hamming distance algorithm, 70.5\% for the Leveinshtein distance algorithm and $70.2 \%$ for the Jaro-Winkler algorithm. Of the three algorithms, Leveinshtein distance has the highest translation accuracy performance.
\end{abstract}

Keywords: translation, indonesian language, minang language, hamming distance, leveinshtein distance, jarowinkler, optical character recognition

${ }^{1}$ Program Studi Informatika, Fakultas Ilmu Komputer, Universitas Pembangunan Nasional Veteran Jakarta;

${ }^{2}$ Badan Pengembangan dan Pembinaan Bahasa, Kementerian Pendidikan dan Kebudayaan; 


\section{PENDAHULUAN}

Bahasa daerah merupakan alat komunikasi intraetnik. Selain itu, bahasa daerah juga berfungsi sebagai pendukung bahasa nasional, yakni bahasa Indonesia. Bahasa daerah juga merupakan salah satu kekayaan budaya yang dimiliki bangsa Indonesia. Oleh karena itu, pelestarian bahasa daerah harus terus digiatkan dan dikembangkan untuk dapat memperkokoh ketahanan budaya bangsa (Asrif 2010).

Kemajuan teknologi harus dapat dimanfaatkan dalam upaya melestarikan bahasa daerah. Teknologi kecerdasan buatan merupakan salah satu teknologi yang dapat menjawab tantangan tersebut. Kecerdasan buatan merupakan sebuah teknologi yang dapat mengadopsi kecerdasan yang dimiliki manusia untuk diimplementasikan ke dalam sebuah komputer. Mesin penerjemah merupakan salah satu teknologi kecerdasan buatan yang dapat digunakan.

Mesin penerjemah bahasa Indonesia ke bahasa daerah sudah banyak dikembangkan. Nuraini dan Firmansyah mengembangkan kamus terjemahan digital bahasa aceh ke Bahasa Indonesia berbasis web (Nuraini dan Firmansyah 2020). Januardi et al. juga mengembangkan aplikasi berbasis Android dalam melakukan prediksi pencarian kata dalam kamus bahasa Manggarai (Nusa Tenggara Timur), Indonesia dan Inggris (Januardi et al. 2019). Priyanto dan Ulinnuha juga melakukan perancangan aplikasi penerjemahan Bahasa Indonesia ke bahasa Jawa berbasis Android (Priyanto dan Ulinnuha 2017).

Dari ketiga penelitian ini, mesin penerjemah memiliki inputan berupa teks yang kemudian teks tersebut diterjemahkan sesuai dengan bahasa yang diinginkan. Selain dalam bentuk teks, mesin penerjemah juga bisa menerjemahkan teks yang terdapat dalam sebuah gambar. Teks yang terdapat di dalam gambar diekstrak terlebih dahulu menjadi teks atau biasa disebut dengan Optical Character Recognition (OCR). Hasil dari OCR berupa teks yang akan diterjemahkan ke dalam bahasa daerah yang diinginkan.

Algoritme Edit Distance banyak digunakan pada pemrosesan data teks khususnya pada mesin penerjemahan. Algoritme Edit Distance merupakan sebuah algoritme yang biasa digunakan untuk mendeteksi kesalahan ejaan. Jika terdapat dua buah kata, maka edit distance adalah jumlah operasi minimum untuk mengubah satu string ke string lainnya. Semakin sedikit jumlah operasinya maka semakin mirip dua kata terebut. Terdapat beberapa algoritme pada Edit Distance, yakni Hamming Distance, Levenshtein Distance dan Jaro-Winkler.

Przybocki et al. menerapkan algoritme Edit Distance dalam mengevaluasi sebuah mesin penerjemah (Przybocki et al. 2006). Pada penelitian Hu et al. (2015) digunakan algoritme Hamming Distance untuk memperkirakan kemiripan dalam pencarian teks. Hossain et al. menggunakan Levenshtein Distance dalam melakukan perbaikan otomatis pada hasil terjemahan bahasa Bengali ke bahasa Inggris dengan tingkat akurasi sebesar 78.13\% (Hossain et al. 2019). Penelitian Wint et al. juga menggunakan Levenshtein Distance untuk melalukan perbaikan ejaan pada dataset sosial media dengan tingkat akurasi 90\% (Wint et al. 2017). Levenshtein Distance juga digunakan untuk melakukan autocomplete dan spell checking dalam proses pencarian data perpustakaan (Yulianto et al. 2018). Cahyono dalam penelitiannya menggunakan algoritme Jaro-Winkler dan algoritme Paragraph Vector dalam melakukan perbandingan kemiripan dokumen pada dokumen ilmiah.

Berdasarkan penelitian-penelitian terdahulu, penulis menggunakan algoritme Edit Distance yakni Hamming Distance, Levenshtein Distance dan Jaro-Winkler dalam menerjemahkan teks bahasa Indonesia ke bahasa daerah dari hasil Optical Character Recognition.

\section{METODE}

Metode penelitian ini secara garis besar diilustrasikan pada Gambar 1. Fokus pembahasan pada tulisan ini pada proses penerjemahan hasil OCR teks bahasa Indonesia ke bahasa daerah. Proses OCR menggunakan model OCR Convolutional Neural Networks (CNN). Setelah 
diperoleh hasil OCR, maka didapatkan teks bahasa Indonesia yang kemudian akan dilakukan pencarian kemiripan teks pada kamus bahasa daerah. Kamus bahasa daerah yang digunakan sebagai sampel penelitian adalah kamus bahasa Minang. Jumlah kata yang digunakan sebanyak 200 kata yang berasal dari daftar kata swadesh. Daftar kata ini merupakan daftar kosa kata dasar yang sering ditemukan di hampir semua bahasa (Maslakhah 2019). Daftar kata ini digunakan sebagai acuan pemilihan kata pada proses penerjemahan kata bahasa Indonesia ke bahasa daerah.

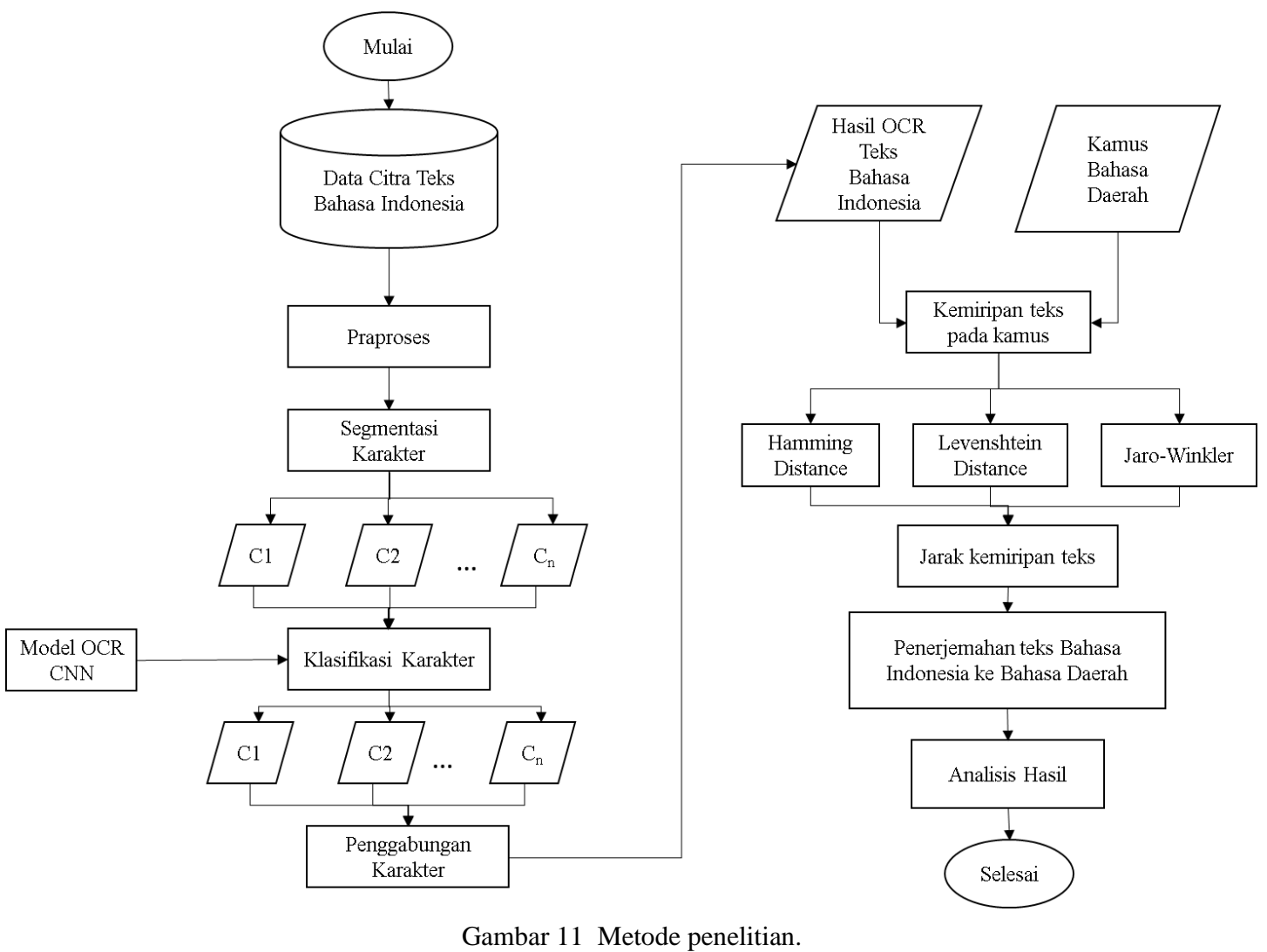

Data citra teks diperoleh dengan pengambilan gambar menggunakan lima jenis perangkat/device yang berbeda, yakni Scanner, Samsung Galaxy J5, iPhone 4, iPhone 5s, dan iPhone 7. Setiap citra teks menggunakan lima fon yang berbeda yakni Arial (fon 1), Bodoni (fon 2), Calibri (fon 3), Helvetica (fon 4) dan Times New Roman (fon 5). Spesifikasi perangkat dapat dilihat pada Tabel 1.

Tabel 1 Tingkat akurasi terjemahan pada device 1

\begin{tabular}{llll}
\hline Jenis Perangkat (Kode) & $\begin{array}{l}\text { Megapixel/ } \\
\text { Scanner Type }\end{array}$ & $\begin{array}{l}\text { Bukaan (f/)/ Sensor } \\
\text { Type }\end{array}$ & $\begin{array}{l}\text { Ukuran piksel/ } \\
\text { Optical Resolution }\end{array}$ \\
\hline Scanner EPSON (D1) & $600 \times 1200 \mathrm{dpi}$ & $\mathrm{CIS}$ & $\begin{array}{l}\text { Flatbed Colour Image } \\
\text { Scanner }\end{array}$ \\
& & & $1.15 \mu \mathrm{m}$ \\
Samsung Galaxy J5 (D2) & $13 \mathrm{MP}$ & $\mathrm{f} / 1.9$ & $1.5 \mu \mathrm{m}$ \\
Iphone 4 (D3) & $15 \mathrm{MP}$ & $\mathrm{f} / 2.8$ & $1.5 \mu \mathrm{m}$ \\
Iphone 5S (D4) & $8 \mathrm{MP}$ & $\mathrm{f} / 2.2$ & $1.22 \mu \mathrm{m}$ \\
Iphone 7 (D5) & $12 \mathrm{MP}$ & $\mathrm{f} / 1.8$ & \\
\hline
\end{tabular}

Setiap citra teks dilakukan praproses berupa thresholding untuk mengubah citra RGB menjadi citra biner. Citra biner selanjutnya dilakukan segmentasi yakni memisahkan setiap huruf yang terdapat pada citra teks. Setiap huruf dari citra teks akan diklasifikasi dengan menggunakan model OCR CNN. Hasil prediksi dari setiap huruf akan digabungkan kembali, sehingga menghasilkan teks bahasa Indonesia. 
Selanjutnya adalah tahapan penerjemahan. Setiap teks bahasa Indonesia hasil prediksi OCR diterjemahkan ke dalam bahasa daerah Minang dengan cara menghitung nilai similarity (kemiripan) teks bahasa Indonesia dari hasil OCR dengan teks bahasa Indonesia yang terdapat dalam kamus bahasa daerah minang. Perhitungan nilai similarity menggunakan tiga metode yakni Hamming Distance, Leveinshtein Distance dan Jaro-Winkler.

\section{Hamming Distance}

Hamming Distance merupakan sebuah algoritme jarak yang dapat menghitung kemiripan dari dua buah kata. Algoritme ini akan membandingkan dua buah kata yang sama dengan membandingkan setiap karakter pada posisi yang sama. Nilai dari hamming distance adalah jumlah karakter yang berbeda pada dua buah kata yang dibandingkan. Operasi yang dilakukan pada hamming distance hanya operasi substitusi yakni operasi menukar huruf. Ilustrasi dari algoritme Hamming Distance dapat dilihat pada Gambar 2.

\begin{tabular}{lcccccc} 
& {$[0]$} & {$[1]$} & {$[2]$} & {$[3]$} & {$[4]$} & {$[5]$} \\
S1 & $\mathrm{b}$ & $\mathrm{a}$ & $\mathrm{h}$ & $\mathrm{a}$ & $\mathrm{s}$ & $\mathrm{a}$ \\
S2 & $\mathrm{b}$ & $\mathrm{a}$ & $\mathrm{t}$ & $\mathrm{o}$ & $\mathrm{s}$ & $\mathrm{a}$ \\
$\begin{array}{l}\text { Hamming } \\
\text { distance }\end{array}$ & - & - & $\mathrm{h}$ & $\mathrm{a}$ & - & - \\
Nilai jarak & 0 & 0 & 1 & 1 & 0 & 0 \\
\multicolumn{5}{l}{ Gambar 12 } & Ilustrasi algoritme Hamming Distance.
\end{tabular}

\section{Leveinshtein Distance}

Jarak dua buah kata pada algoritme Leveinshtein Distance adalah dengan menghitung jumlah transformasi kata yang diperlukan untuk mengubah kata 1 menjadi kata 2. Operasi yang digunakan yakni penghapusan, penyisipan dan penggantian (Hossain et al. 2019). Ilustrasi algoritme Leveinshtein Distance dapat dilihat pada Tabel 2.

Tabel 2 Ilustrasi algoritme Leveinshtein Distance

\begin{tabular}{lcc}
\hline Operasi & S $_{\text {sumber }}=$ bakhosa & S $_{\text {traget }}$ bahasa \\
\hline Substitusi k dengan h & bahhosa & bahasa \\
Substitusi h dengan a & bahaosa & bahasa \\
Substitusi o dengan s & bahassa & bahasa \\
Substitusi s dengan a & bahasaa & bahasa \\
Meghapus a & bahasa & bahasa \\
\hline Total transformasi & & 5 \\
\hline
\end{tabular}

\section{Jaro-Winkler}

Berbeda dengan Hamming Distance dan Leveinshtein Distance, dimana semakin banyak operasi yang dibutuhkan untuk mentranformasikan kata 1 dengan kata 2, maka semakin berbeda dua buah kata tersebut. Pada Jaro-Winkler, semakin tinggi nilainya, maka akan semakin mirip dua buah kata tersebut. Terdapat tiga tahapan dalam algoritme Jaro-Winkler: 1) Menghitung panjang kata; 2) Menghitung jumlah karakter yang sama dalam dua buah kata; dan 3). Menghitung jumlah tansposisi (Kornain et al. 2014). Rumus menghitung jarak pada algoritme Jaro-Winkler dapat dilihat pada Persamaan 1.

$$
d_{j w}=d_{j}+\left(l \cdot p\left(1-d_{j}\right), \text { dengan } d_{j}=\frac{1}{3}+\left(\frac{m}{\left|s_{1}\right|}+\frac{m}{\left|s_{2}\right|}+\frac{m-t}{m}\right)\right.
$$

dengan $d_{j w}$ adalah jarak Jaro-Winkler, $l$ adalah panjang karakter yang sama sampai ditemukan ketidaksamaan, $p$ adalah konstanta scaling factor. $d_{j}$ adalah jarak Jaro untuk kata $1\left(s_{1}\right)$ dan kata $2\left(s_{2}\right), m$ adalah jumlah karakter yang sama dan $t$ adalah jumlah transposisi. 


\section{Evaluasi}

Untuk mengevaluasi performa masing-masing metode, pengujian akan dilakukan dengan menggunakan nilai akurasi. Nilai evaluasi ini digunakan untuk mengetahui performa metode Edit Distance dalam menerjemahkan hasil OCR teks bahasa Indonesia ke bahasa daerah. Untuk menghitung nilai akurasi menggunakan persamaan di bawah ini:

$$
\text { Akurasi }=\frac{\text { jumlah kata diterjemahkan benar }}{\text { total teks hasil OCR }} \times 100 \%
$$

\section{HASIL DAN PEMBAHASAN}

Jumlah citra teks hasil OCR diperoleh sebanyak 200 kata. Daftar kata diambil dari daftar data swadesh yang diperoleh dari Laboratorium Kebinekaan Bahasa dan Sastra, Kementerian Pendidikan dan Kebudayaan. Kamus bahasa daerah yang digunakan merupakan kamus daerah bahasa Minang yang berasal dari Sumatera Barat. Daftar kata dapat dilihat pada Tabel 3.

Tabel 3 Kamus Bahasa Indonesia dan Bahasa Minang

\begin{tabular}{|c|c|c|c|c|c|c|c|}
\hline \multicolumn{8}{|c|}{ Daftar kata Swadesh } \\
\hline $\begin{array}{l}\text { Bahasa } \\
\text { Indonesia }\end{array}$ & $\begin{array}{l}\text { Bahasa } \\
\text { Minang }\end{array}$ & $\begin{array}{l}\text { Bahasa } \\
\text { Indonesia }\end{array}$ & $\begin{array}{l}\text { Bahasa } \\
\text { Minang }\end{array}$ & $\begin{array}{l}\text { Bahasa } \\
\text { Indonesia }\end{array}$ & $\begin{array}{l}\text { Bahasa } \\
\text { Minang }\end{array}$ & $\begin{array}{l}\text { Bahasa } \\
\text { Indonesia }\end{array}$ & $\begin{array}{l}\text { Bahasa } \\
\text { Minang }\end{array}$ \\
\hline Abu & $\mathrm{Abu}$ & Danau & Danau & Kanan & Kanan & Pendek & Pendek \\
\hline Air & Aia & Darah & Darah & Karena & Karano & Peras & Pareh \\
\hline Akar & Aka & Datang & Tibo & Kecil & Ketek & Perempuan & Padusi \\
\hline Anak & Anak & Daun & Daun & Kepala & Kapalo & Pergi & Pai \\
\hline Angin & Angin & Debu & Debu & Kering & Kariang & Perut & Paruik \\
\hline Anjing & Anjiang & Dekat & Dakek & Kiri & Kida & Pikir & Pikia \\
\hline Apa & Apo & Dengan & Jo & Kotor & Kumuah & Pohon & Pohon \\
\hline Api & Api & Dengar & Danga & Kuku & Kuku & Potong & Potong \\
\hline Asap & Asok & Dingin & Dingin & Kulit & Kulik & Punggung & Pungguang \\
\hline Awan & Awan & Dorong & Dorong & Kuning & Kuniang & Pusar & Pusek \\
\hline Ayah & Apak & Dua & Duo & Kutu & Kutu & Putih & Putiah \\
\hline Bagaimana & $\mathrm{Baa}$ & Duduk & Duduak & Lain & Lain & Rambut & Rambuik \\
\hline Bagus & Rancak & Ekor & Ikua & Langit & Langik & Rumput & Rumpuik \\
\hline Baik & Elok & Empat & Ampek & Laut & Lauik & Sakit & Sakik \\
\hline Bakar & Baka & Engkau & Waang & Lebar & Leba & Satu & Ciek \\
\hline Balik & Baliak & Gali & Galia & Leher & Lihia & Saya & Awak \\
\hline Banyak & Banyak & Garam & Garam & Lelaki & Lelaki & Sayap & Sayok \\
\hline Baring & Golek & Garuk & Garuak & Lempar & Gado & Sedikit & Saketek \\
\hline Baru & Baru & Gemuk & Gamuak & Licin & Licin & Sempit & Sampiak \\
\hline Basah & Babiyak & Gigi & Gigik & Lidah & Lidah & Semua & Kasado \\
\hline Batu & Batu & Gigit & Gigik & Lihat & Caliak & Siang & Siang \\
\hline Beberapa & Bara & Gosok & Gosok & Lima & Limo & Siapa & Sia \\
\hline Benar & Bana & Gunung & Gunuang & Ludah & Ludah & Suami & Suami \\
\hline Bengkak & Bangkek & Hantam & Antam & Lurus & Luruih & Sungai & Batang Aia \\
\hline Benih & Baniah & Hapus & Apuih & Lutut & Lutuik & Tahu & $\mathrm{Tau}$ \\
\hline Berat & Barek & Hati & Ati & Main & Main & Tahun & Tahun \\
\hline Berburu & Baburu & Hidung & Hiduang & Makan & Makan & Tajam & Tajam \\
\hline Berdiri & Tagak & Hidup & Hiduik & Malam & Malam & Takut & Takuik \\
\hline Berenang & Baranang & Hijau & Hijau & Mata & Mato & Tali & Tali \\
\hline Beri & Agiah & Hisap & Hisap & Matahari & Matoari & Tanah & Tanah \\
\hline Berjalan & Berjalan & Hitam & Hitam & Mati & Mati & Tangan & Tangan \\
\hline Berkata & Bakecek & Hitung & Hituang & Membelah & Mambalah & Tarik & Tariak \\
\hline Berkelahi & Bacakak & Hujan & Ujan & Mengalir & Mangalia & Tebal & Taba \\
\hline Besar & Gadang & Hutan & Utan & Mengapung & Maapuang & Telinga & Talingo \\
\hline Bilamana & Bilo & Ia & Inyo & Menikam & Manikam & Telur & Talua \\
\hline Binatang & Binatang & Ibu & Bundo & Merah & Merah & Terbang & Tabang \\
\hline Bintang & Bintang & Ikan & Ikan & Mereka & Mereka & Tertawa & Galak \\
\hline Buah & Buah & Ikat & Ikek & Minum & Minum & Tetek & Tetek \\
\hline Bulan & Bulan & Ini & Iko & Mulut & Muluik & Tidak & Indak \\
\hline Bulu & Bulu & Isteri & Bini & Muntah & Muntah & Tidur & Lalok \\
\hline Bunga & Bungo & Itu & $\mathrm{Tu}$ & Nama & Namo & Tiga & Tigo \\
\hline Bunuh & Bunuah & Jahit & Jaik & Nanti & Beko & Tipis & Tipih \\
\hline Buruk & Buruak & Jantung & Jantuang & Napas & Napas & Tiup & Tiup \\
\hline Burung & Buruang & Jatuh & Jatuah & Nyanyi & Nyanyi & Tongkat & Tungkek \\
\hline Busuk & Busuak & Jauh & Jauah & Orang & Urang & Tua & Tuo \\
\hline Cacing & Caciang & Kabut & Kabut & Pada & Pado & Tulang & Tulang \\
\hline Cium & Ineh & Kaki & Kaki & Panas & Paneh & Tumpul & Tumpua \\
\hline Cuci & Basuah & Kalau & Kalau & Panjang & Panjang & Uang & Pitiah \\
\hline Daging & Dagiang & Kami & Kami & Pasir & Pasia & Ular & Ula \\
\hline Dan & Dan & Kamu & Waang & Pegang & Pacik & Usus & Usus \\
\hline
\end{tabular}


Citra teks hasil OCR banyak mengalami kegagalan dalam memprediksi huruf, khususnya untuk huruf i dan j. Pada dua huruf tersebut akan tersegmentasi menjadi dua buah objek dikarenakan terdapatnya objek titik. Contoh kegagalan segmentasi dapat dilihat pada Gambar 3 .
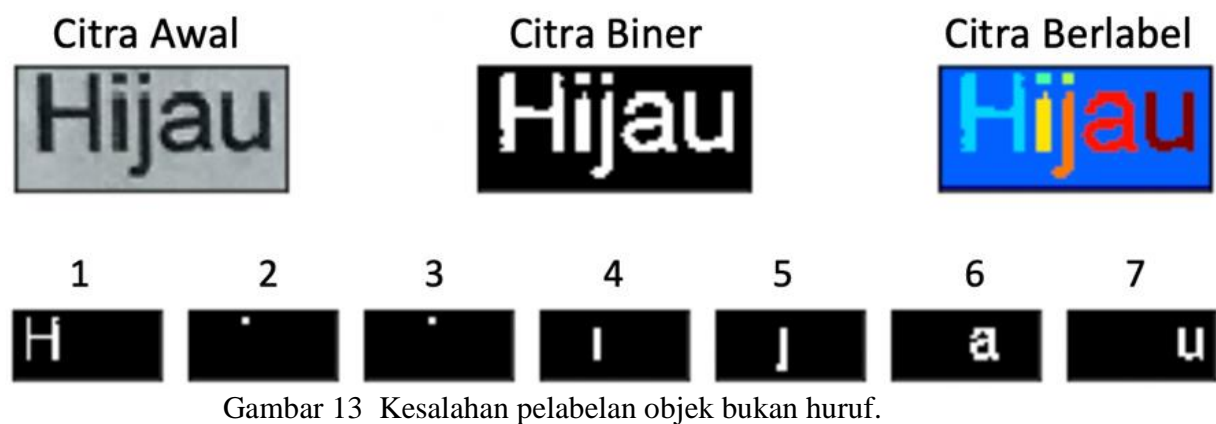

Tabel 4 Akurasi klasifikasi kata berdasarkan device dan font

\begin{tabular}{ccrrrrr}
\hline Font/ & \multicolumn{7}{c}{ Akurasi (\%) } \\
\cline { 2 - 7 } Perangkat & D1 & D2 & D3 & D4 & D5 & Rata-rata \\
\hline F1 & 85.0 & 81.0 & 25.0 & 82.5 & 96.0 & 73.9 \\
F2 & 13.0 & 5.0 & 1.0 & 7.5 & 17.5 & 8.8 \\
F3 & 50.5 & 80.0 & 4.0 & 48.0 & 89.5 & 54.4 \\
F4 & 85.5 & 88.5 & 46.0 & 85.5 & 96.0 & 80.3 \\
F5 & 43.5 & 45.5 & 4.5 & 39.5 & 48.0 & 36.2 \\
\hline Rata-rata & 55.5 & 60.0 & 16.1 & 52.6 & 69.4 & 50.72 \\
\hline
\end{tabular}

Hasil klasifikasi 200 citra teks dapat dilihat pada Tabel 4. Akurasi rata-rata untuk semua jenis perangkat dan fon adalah 50.72\%. Akurasi terendah, jenis perangkat 3 (Iphone 4) dan tertinggi pada jenis perangkat 5 (Iphone 7). Sementara itu, untuk jenis fon, akurasi terendah pada fon 2 (Bodoni) dan akurasi tertinggi pada fon 4 (Helvetica).

Selanjutnya, hasil OCR dilakukan terjemahan menggunakan algoritme Hamming Distance, Leveinshtein Distance dan Jaro-Winkler. Akurasi terjemahan kata menggunakan algoritme hamming distance dapat dilihat pada Tabel 5. Akurasi rata-rata terjemahan kata menggunakan algoritme Hamming Distance adalah $68.34 \%$.

Tabel 5 Akurasi terjemahan kata menggunakan algoritme Hamming Distance

\begin{tabular}{ccccccc}
\hline Fon/ & \multicolumn{7}{c}{ Akurasi (\%) } \\
\cline { 2 - 7 } Perangkat & D1 & D2 & D3 & D4 & D5 & Rata-rata \\
\hline F1 & 95.0 & 89.5 & $\mathbf{6 8 . 5}$ & $\mathbf{9 5 . 0}$ & 95.0 & 88,6 \\
F2 & 35.0 & 19.5 & 5.5 & 25.0 & 29.0 & 22.8 \\
F3 & $\mathbf{9 1 . 0}$ & $\mathbf{9 5 . 5}$ & 43.5 & $\mathbf{9 2 . 5}$ & 95.5 & 83.6 \\
F4 & $\mathbf{9 5 . 5}$ & 94.0 & $\mathbf{7 7 . 0}$ & 94.5 & 95.5 & 91.3 \\
F5 & 66.0 & 62.0 & 25.0 & 64.5 & 59.5 & 55.4 \\
\hline Rata-rata & 76.5 & 72.1 & $\mathbf{4 3 . 9}$ & 74.3 & 74.9 & 68.34 \\
\hline
\end{tabular}

Contoh keberhasilan algoritme Hamming Distance dalam melakukan terjemahan teks bahasa Indonesia hasil OCR dapat dilihat pada Gambar 4. Hasil OCR yang tadinya terjadi kegagalan yakni teks "abu" terbaca "auu". Namun setelah dilakukan Perhitungan Hamming Distance pada kamus bahasa daerah diperoleh kemiripan kata dengan kata abu, sehingga hasil terjemahan yang dihasilkan benar. 

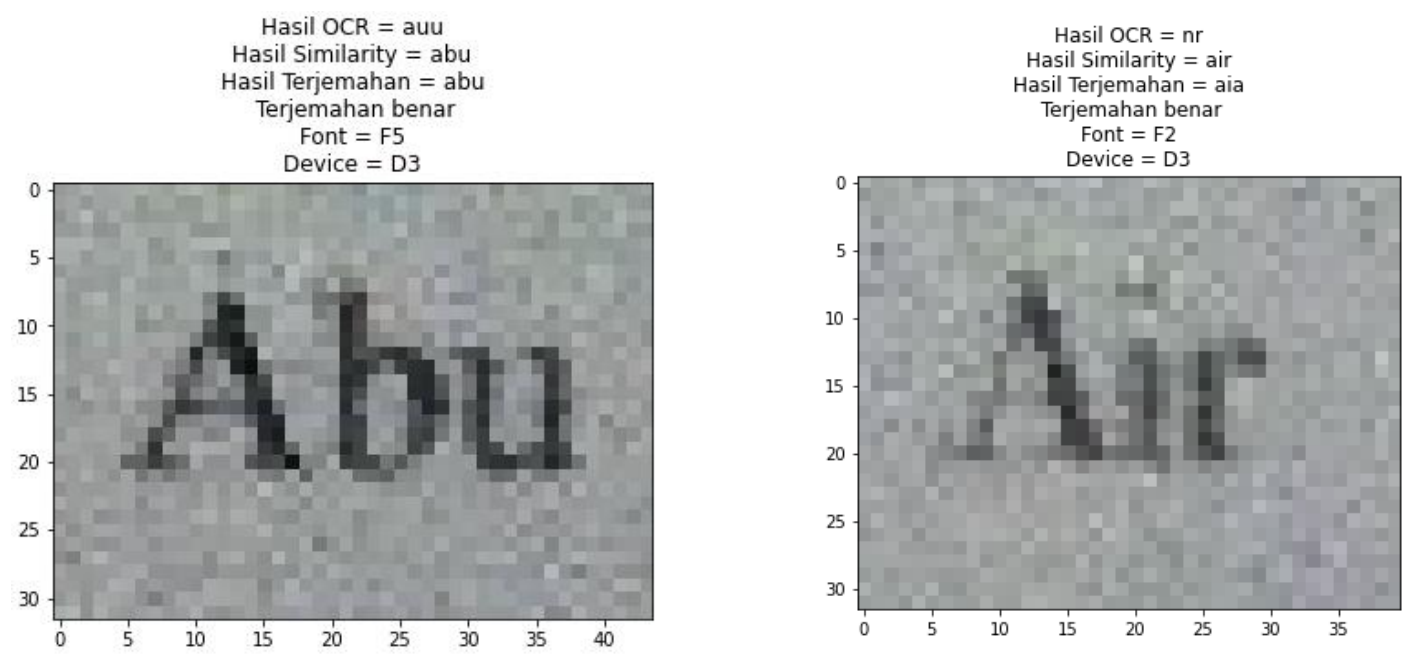

Gambar 14 Kasus berhasil pada algoritme Hamming Distance.

Akurasi terjemahan kata menggunakan algoritme Leveinshtein Distance dapat dilihat pada Tabel 6. Akurasi rata-rata terjemahan kata menggunakan algoritme ini adalah $70.5 \%$.

Tabel 6 Akurasi terjemahan kata menggunakan algoritme Leveinshtein Distance

\begin{tabular}{ccccccc}
\hline Fon/ & \multicolumn{7}{c}{ Akurasi (\%) } \\
\cline { 2 - 7 } Perangkat & D1 & D2 & D3 & D4 & D5 & Rata-rata \\
\hline F1 & $\mathbf{9 5 . 5}$ & $\mathbf{9 1 . 0}$ & 65.0 & $\mathbf{9 5 . 0}$ & $\mathbf{9 5 . 5}$ & 88.4 \\
F2 & 42.0 & $\mathbf{2 3 . 5}$ & 7.0 & $\mathbf{3 1 . 0}$ & 43.5 & 29.3 \\
F3 & 89.5 & $\mathbf{9 5 . 5}$ & 39.5 & 89.5 & $\mathbf{9 6 . 0}$ & 82.0 \\
F4 & $\mathbf{9 5 . 5}$ & $\mathbf{9 5 . 0}$ & $\mathbf{7 7 . 0}$ & 94.5 & $\mathbf{9 6 . 0}$ & 91.6 \\
F5 & 70.5 & 70.5 & $\mathbf{2 7 . 0}$ & 68.5 & 69.5 & 61.2 \\
\hline Rata-rata & $\mathbf{7 8 . 6}$ & $\mathbf{7 5 . 1}$ & 43.1 & $\mathbf{7 5 . 7}$ & 80.1 & 70.5 \\
\hline
\end{tabular}

Contoh keberhasilan algoritme Leveinsthein Distance dalam melakukan terjemahan teks bahasa Indonesia hasil OCR dapat dilihat pada Gambar 5. Hasil OCR yang tadinya terjadi kegagalan yakni teks "abu" terbaca "niu". Namun setelah dilakukan perhitungan Leveinshtein Distance pada kamus bahasa daerah diperoleh kemiripan kata dengan kata abu sehingga hasil terjemahan yang dihasilkan benar.
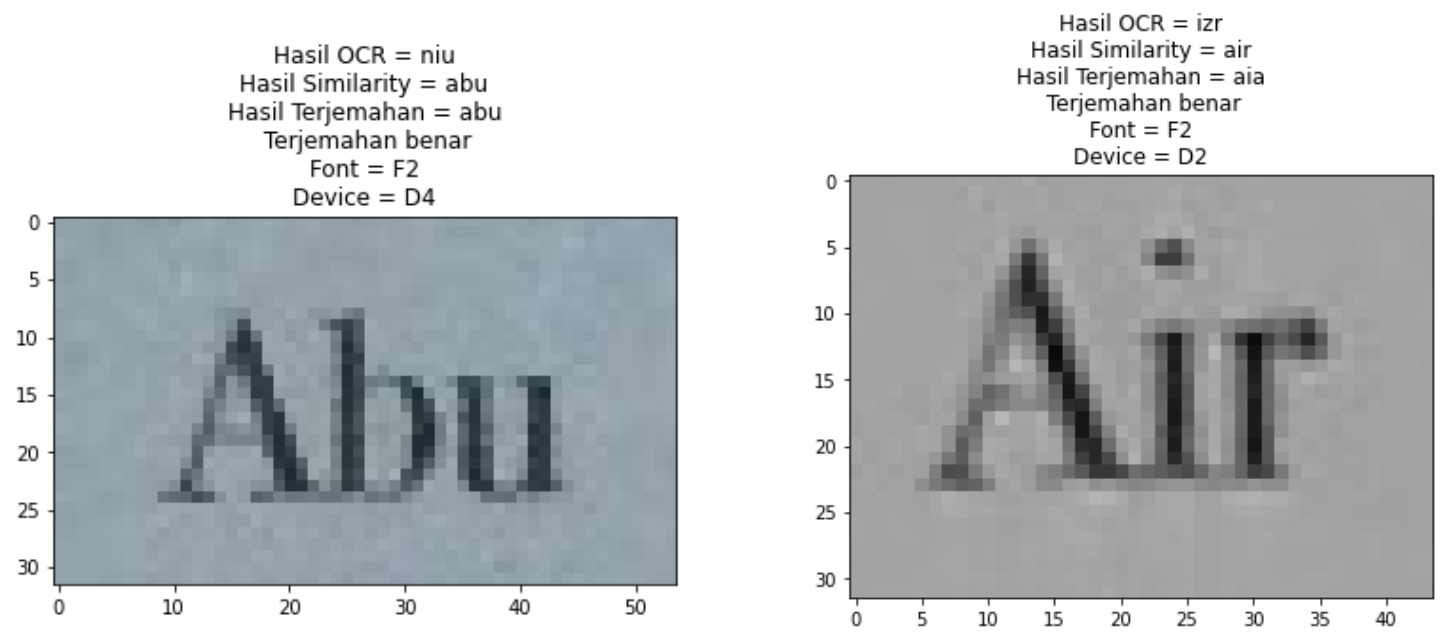

Gambar 15 Kasus berhasil pada algoritme Leveinsthein Distance.

Akurasi terjemahan kata menggunakan algoritme Jaro-Winkler dapat dilihat pada Tabel 7. Akurasi rata-rata terjemahan kata menggunakan algoritme Jaro-Winkler adalah 70.2\%. 
Tabel 7 Akurasi Terjemahan Kata Menggunakan Algoritme Leveinshtein Distance

\begin{tabular}{ccccccc}
\hline Fon/ & \multicolumn{7}{c}{ Akurasi (\%) } \\
\cline { 2 - 7 } Perangkat & D1 & D2 & D3 & D4 & D5 & Rata-rata \\
\hline F1 & $95.0 \%$ & $89.0 \%$ & $63.0 \%$ & $94.5 \%$ & $95.0 \%$ & 87.3 \\
F2 & $\mathbf{4 2 . 5 \%}$ & $21.0 \%$ & $\mathbf{1 0 . 5 \%}$ & $29.0 \%$ & $\mathbf{5 0 . 0 \%}$ & 30.6 \\
F3 & $84.5 \%$ & $95.0 \%$ & $32.0 \%$ & $83.5 \%$ & $95.0 \%$ & 78.0 \\
F4 & $94.0 \%$ & $93.5 \%$ & $76.5 \%$ & $\mathbf{9 5 . 0 \%}$ & $94.5 \%$ & 90.7 \\
F5 & $\mathbf{7 6 . 0 \%}$ & $\mathbf{7 2 . 0 \%}$ & $22.0 \%$ & $\mathbf{7 3 . 5 \%}$ & $\mathbf{7 7 . 5 \%}$ & 64.2 \\
\hline Rata-rata & $\mathbf{7 8 . 4 \%}$ & $74.1 \%$ & $40.8 \%$ & $75.1 \%$ & $82.4 \%$ & 70.2 \\
\hline
\end{tabular}

Contoh keberhasilan algoritme Jaro-Winkler distance dalam melakukan terjemahan teks bahasa Indonesia hasil OCR dapat dilihat pada Gambar 6. Hasil OCR yang tadinya terjadi kegagalan yakni teks "abu" terbaca "niu". Namun setelah dilakukan perhitungan Leveinshtein Distance pada kamus bahasa daerah diperoleh kemiripan kata dengan kata abu sehingga hasil terjemahan yang dihasilkan benar.
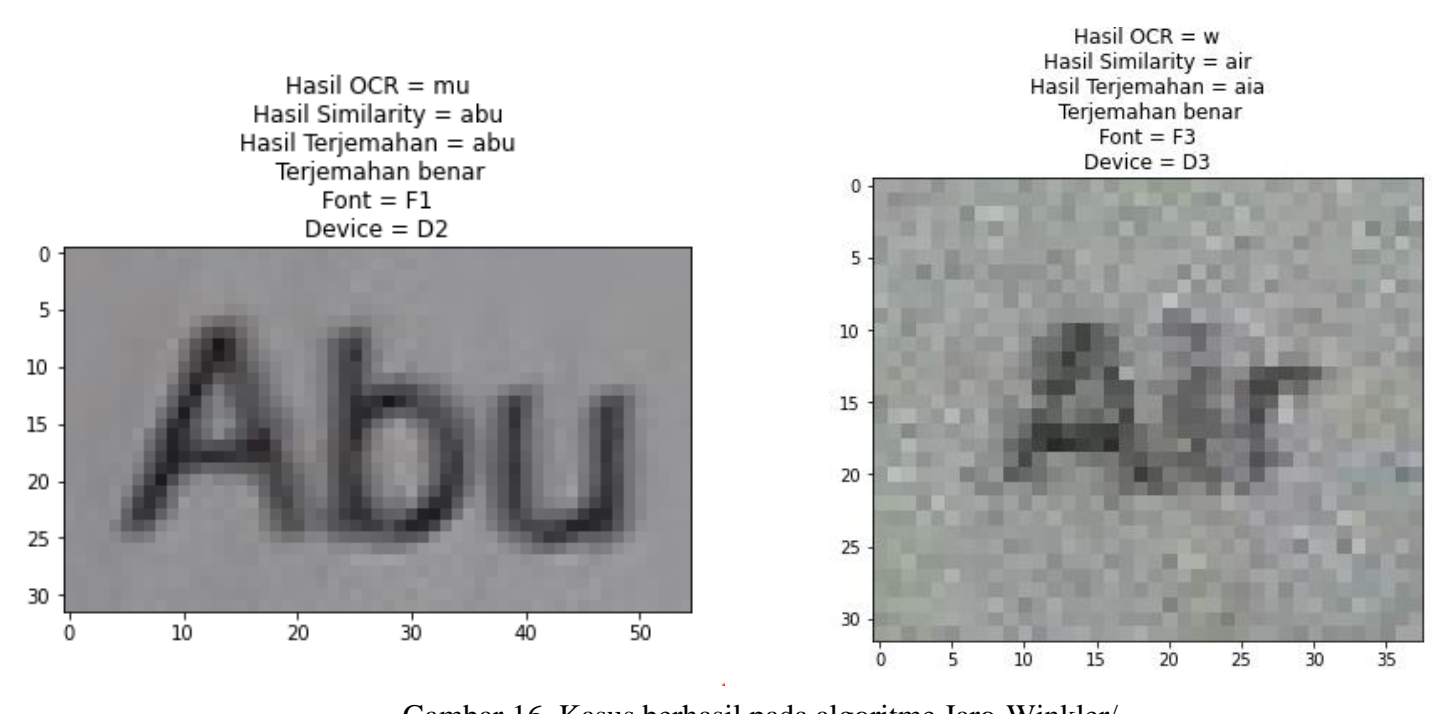

Gambar 16 Kasus berhasil pada algoritme Jaro-Winkler/

Algoritme Hamming Distance, Leveinshtein Distance dan Jaro-Winkler dapat meningkatkan hasil pengenalan teks hasil OCR. Pada pengenalan teks hasil OCR, akurasi ratarata diperoleh sebesar 50.72\%. Hasil ini meningkat dengan menggunakan Algoritme Hamming Distance dengan akurasi rata-rata $68.34 \%$, Leveinshtein Distance dengan akurasi rata-rata $70.5 \%$ dan Jaro-Winkler dengan akurasi rata-rata 70.2\%. Dari ketiga algoritme tersebut, algoritme Leveinshtein Distance memiliki tingkat keberhasilan paling tinggi.

\section{SIMPULAN}

Pada penelitian ini telah dilakukan penerjemahan teks bahasa Indonesia ke bahasa daerah dari hasil Optical Character Recognition (OCR) pada citra teks bahasa Indonesia. Penerjemahan dilakukan menggunakan algoritme similarity yakni Edit Distance. Algoritmealgoritme Edit Distance yang digunakan adalah Hamming Distance, Leveinshtein Distance dan Jaro-Winkler. Algoritme Edit Distance dapat meningkatkan hasil akurasi terjemahan dari klasifikasi kata pada citra teks. Sebelum dilakukan terjemahan akurasi klasifikasi kata yakni $50.72 \%$. Akurasi ini meningkat setelah diterapkan algoritme Edit Distance untuk mencari kemiripan kata pada kamus bahasa daerah. Dari ketiga algoritme Edit Distance, Leveinshtein Distance memiliki akurasi paling tinggi yakni $70.5 \%$. 


\section{UCAPAN TERIMA KASIH}

Terima kasih kepada Universitas Pembangunan Nasional Veteran Jakarta yang telah mendanai penelitian ini pada hibah penelitian internal Riset Dosen Pemula tahun 2020.

\section{DAFTAR PUSTAKA}

Asrif. 2010. Pembinaan dan Pengembangan Bahasa Daerah dalam Memantapkan Kedudukan dan Fungsi Bahasa Indonesia. Mabasan 4(1): 11-23.

Hossain MM, Labib MF, Rifat AS, Das AK, Mukta M. 2019. Auto-correction of English to Bengali Transliteration System using Levenshtein Distance. 2019 7th International Conference on Smart Computing and Communications, ICSCC 2019. IEEE. hlm 1-5. doi: 10.1109/ICSCC.2019.8843613.

Hu H, Zhang L, Wu J. 2015. Hamming distance based approximate similarity text search algorithm. 2015 7th International Conference on Advanced Computational Intelligence, ICACI 2015. hlm 1-6. doi: 10.1109/ICACI.2015.7184772.

Januardi DO, Budianto AE, S MPT. 2019. Prediksi Pencarian Kata dengan Algoritme Levenshtein Distance di dalam Kamus Bahasa Manggarai, Indonesia dan Inggris Berbasis Android. hlm. 45-51.

Kornain A, Yansen F, Tinaliah T. 2014. Penerapan Algoritme Jaro-Winkler Distance Untuk Sistem Pendeteksi Plagiarisme Pada Dokumen Teks Berbahasa Indonesia. Program Studi Teknik Informatika STMIK GI MDP. hlm 1-10. Tersedia pada: http://eprints.mdp.ac.id/1068/.

Maslakhah S. 2019. Penerapan metode. Jurnal Ilmiah Bahasa, Sastra, dan Pengajarannya 27(2): 159-167. Tersedia pada: https://journal.uny.ac.id/index.php/diksi/article/view/23098.

Nuraini, Firmansyah B. 2020. Implementasi Algoritme Knuth Morris Prath Untuk Kamus Terjemahan Digital Aceh - Bahasa Indonesia Berbasis Web. Jurnal Nasional Informatika. 1(1): 66-75. Tersedia pada: https://journal.uny.ac.id/index.php/diksi/article/view/23098.

Priyanto A, Ulinnuha F. 2017. Perancangan Aplikasi Penerjemah Bahasa Indonesia Ke Bahasa Jawa Untuk Media Bantu Belajar Siswa SMK Salafiyah Berbasis Android. Indonesian Journal of Network \& Security 6(4): 39-46. Tersedia pada: http://ijns.org/journal/index.php/ijns/article/view/1473.

Przybocki M, Sanders G, Le A. 2006. Edit distance: A metric for machine translation evaluation. Proceedings of the 5th International Conference on Language Resources and Evaluation, LREC 2006. hlm 2038-2043.

Wint ZZ, Ducros T, Aritsugi M. 2017. Spell corrector to social media datasets in message filtering systems. 2017 12th International Conference on Digital Information Management, ICDIM 2017, 2018-Janua(Icdim). hlm 209-215. doi: 10.1109/ICDIM.2017.8244677.

Yulianto MM, Arifudin R, Alamsyah A. 2018. Autocomplete and Spell Checking Levenshtein Distance Algorithm To Getting Text Suggest Error Data Searching In Library. Scientific Journal of Informatics 5(1): 75. doi: 10.15294/sji.v5i1.14148. 